\title{
Challenges and Prospects of Zimbabwe's Command Farming in Unlocking the Country's Smallholder Agricultural Economy
}

\author{
Chisango Future Fortune Tichakunda \\ Faculty of Agriculture, Zimbabwe Open University, Harare, Zimbabwe
}

\section{Email address:}

fchisango5@yahoo.com, fortunechisah@gmail.com

\author{
To cite this article: \\ Chisango Future Fortune Tichakunda. Exploring Challenges and Prospects of Zimbabwe's Command Farming in Unlocking the Country's \\ Smallholder Agricultural Economy; a Case of Bindura District in Mashonaland Central Province. International Journal of Agricultural \\ Economics. Vol. 3, No. 4, 2018, pp. 76-82. doi: 10.11648/j.ijae.20180304.13
}

Received: May 31, 2018; Accepted: July 7, 2018; Published: July 31, 2018

\begin{abstract}
The study sought to establish and analyze the challenges and prospects of Zimbabwe's command farming in unlocking the country's smallholder agricultural economy with particular reference to smallholder rural and A1 resettlement farmers in Bindura district of Zimbabwe. The main objective central to the study was; to examine challenges and prospects of the command farming initiative as a way of advancing the country's agricultural sector, in an endeavor to curb poverty and food insecurity among the marginalized farming communities. To achieve this, a descriptive study design was used to select a sample of one hundred (100) participants who included ordinary grain producers, village heads, agricultural extension officers, and heads of government departments. A purposive or judgmental sampling technique was employed to select respondents for the study. To solicit for the relevant information unstructured interviews, key informant interviews and secondary sources of data were used. The generated data was finally subjected to descriptive statistics where frequency counts, means and percentages were employed, to make conclusive deductions from the findings. It was established that instead of being a panacea to food security quagmires bedeviling communities, Zimbabwe's command agriculture is faced with numerous challenges due to disparity in the perceived outcomes of the new program by the farming community and the authoritarian implementers. This has resulted in a stalemate, which can only be solved by considering the initiative as a collective issue where communities and other stakeholders play a pivotal role for the attainment of the desired outcomes. It is critical that the government can only get the agricultural economy fixed through robust integration of all stakeholders and resource poor farmers at grassroots in important decision making structures.
\end{abstract}

Keywords: Challenges, Prospects, Command Farming, Agricultural Economy, And Free Marketing Systems

\section{Introduction}

Since the year 2000 there have been major changes in the agrarian economy of Zimbabwe. Extensive poorly planned land redistribution aimed at redressing the skewed land tenure systems in the country resulted in significant backward shifts in agricultural productivity. According to Obi and Chisango [8] the period after the brutal invasions of the commercial farms marked the beginning of the demise of Zimbabwe's agricultural sector, as the country that was once dubbed the bread basket of Africa became a basket case and had to depend on vast volumes of international food aid to avert huge food deficits faced nationwide. It is imperative that in an effort to resuscitate the agricultural sector the government of Zimbabwe launched and tried a number of adhoc initiatives such as Operation Feed the Nation "Maguta", the Presidential Input Scheme and the current Command Agriculture Program which is aimed at mobilizing sustainable and affordable funding for the new farmers who lack access to credit lines as they do not possess property rights which can be attached as collateral when accessing funds from financing institutions.

The initial programs tried never yielded desired outcomes, of boosting agricultural productivity as the facilities were 
abused by the elite government officials at the inception/ infancy stage. It is therefore in this trajectory that though the sudden collapse of the agricultural sector and its catastrophic impact on the country's economy has stimulated the introduction of the command agriculture which never made significant improvements on the country's agricultural sector Chandiposha [1]. The new arrangement registered little success owing to a plethora of challenges surrounding its implementation strategies and disparity in the perceived outcomes of the program by the farming community and the authoritarian implementers. It is therefore imperative that in an endeavor to establish the impediments hindering the proper implementation and adoption of the program, a study's was carried out in selected resettlement farms of Bindura district; Zimbabwe. Central to the study was to attempt to contribute to a better understanding that the government of Zimbabwe can only get the agricultural economy fixed through robust integration of all stakeholders and resource poor farmers at grassroots in important decision making structures.

\section{Background of the Study}

Command Agriculture scheme endorsed by the Government of Zimbabwe during the 2015 to 2016 farming season was meant to mobilize sustainable and affordable funding for the agricultural sector where farmers were supposed to benefit from the agricultural inputs in an endeavor to boost production of strategic crops to restore sanity in the provision of adequate food and nutrition to the rural populace. As dictates of a command economy system it was therefore mandatory that the government had to prescribe the types of crops to be produced by farmers, determine volumes to be produced and the price at which the produce were to be sold, hence depriving producers of access to more lucrative free marketing systems. If appropriately executed the scheme was meant to ensure total eradication of the incessant food shortages and enhance self-sufficiency among smallholder rural farming communities as cited by Chisoko and Zharare [4]. They assert that the scheme's trajectory was to boost the production capacity of the local farmers hence substitute food imports which impacted negatively on the national economy. The initiative was embraced as a noble development as it was perceived as a catalyst for food, nutrition and economic empowerment of local communities through revitalization of the smallholder rural agricultural sector.

Opponents to the new arrangement however argue that failure by the resettled farmers to produce adequate yields to match the food requirements of the ever growing population and the escalating demand for exports to quench the existing food deficits in the country did not warrant government to adopt a command agrarian system as they opine that there is need for farmers to have the liberty to acquire agricultural inputs from suppliers of their own choice without strings attached and market their produce in liberalized open markets where super profits can be realized. Nevertheless, proponents as cited by Pfukwa [9] perceive adoption of such schemes, which are regarded an offshoot of a command economy structure vital as they give governments the autonomous power to control all economic activities surrounding the production and marketing of strategic crops.

At its inception Zimbabwe's command farming has been hailed for registering remarkable success as yields realized in the first season surpassed the targeted yield of 2 million metric tons of cereal/maize perceived adequate to meet the country's annual food requirements. However, the progression of the program later received strong criticism from a larger section of the population due to unorthodox implementation strategies employed by the government of Zimbabwe as state machinery /military was used in the mobilization and distribution of the much needed resources to farmers Chandiposha [1]. According to Chisoko and Zharare [4] this agitated fear among the farming communities who became skeptical about the scheme which they viewed as a political gimmick designed for gaining political mileage by a faction of the ruling party in the country. Again conditions of the scheme stipulating that farmers had to surrender a greater part of their yield, (about 3 tons per hectare) to the Grain Marketing Board (GMB); a government parastatal as a way of servicing the loan was considered a stumbling block. This was a nightmare for the majority of the farmers as their average yield (Total Physical Product TPP) normally staggered at 1.5 tons/ hectare. Thus this coupled with the prevailing monopolistic nature in the marketing of the produce where the parastatal had the autonomous power to set the producer price which in most cases would not tally with the production costs was detrimental to the farmer. Chishamba and Mangudhla [3] opines that it is therefore imperative that robust policy measures need to be formulated and implemented by real technocrats rather than employing the services of state machinery that is synonymous with the use of coercive power as they normally give commands and directives to farmers. They noted that proper planning, policy consistency and a robust supportive framework in terms of funding and incentivizing participating farmers was paramount in stimulating production to attain the targeted yield levels. It is thus critical that there is need by the government to stick to the principles of a free-market economy and refrain from interfering with the market-based economic systems, as the phenomenal command approaches have failed economies elsewhere.

According to Food and Agriculture Organization [5] Zimbabwe's mandate in the Southern African Development Community (SADC) region, at its inception in 1980 was to ascertain access to adequate nutrition and food security by citizens in all member states in the region. As such it was imperative that for the country to reclaim its former status of being the bread basket of Africa, robust market driven land tenure systems and agrarian reforms independent of the dubious indigenization policies had to be adopted. Though assumed that the government of Zimbabwe has for long been devoted to the expansion of agricultural productivity through endeavors such as farm mechanization programmes 
particularly post Fast Track Land Reform (FTLR), Obi and Chisango [8] cited that the period after the brutal invasion of the commercial farms marked the beginning of the demise of the country's agricultural sector, as a country that was once dubbed the bread basket of Africa became a basket case and had to depend on vast volumes of international food aid to avert huge deficits faced nationwide. Pfukwa [9] says the sudden collapse of the agricultural sector and its catastrophic impact on the country's economy thus exacerbated the introduction of the command agriculture which was perceived as the lasting solution to the incessant food shortages in the country. The initiative was therefore intended to embrace and galvanize some clusters; as enshrined in the country's Developmental Master Plan coined the Zim-Asset Blue Print; where irrigation infrastructural development was meant to augment command agriculture in enhancing food security and nutrition through cushioning the drastic impact of climate change.

It is worth noting that the government of Zimbabwe's vision of achieving a robust agricultural economy became strongly biased to a command system where all frontiers of agricultural production were to operate under the dictates of the new framework hence the emergence of; Command Maize, Command Soya bean, Command Livestock, Command Fisheries and wildlife, an endeavor perceived by the generality as an undertaking aimed at putting all viable agricultural entities under the reigns of the state, hence barring other potential private competitors mainly contractors from participating in the lucrative ventures. Thus adoption of the Command Agriculture was necessitated by the fact that since year 2000 with the launch of the fast track land reform programme, Zimbabwe's economy has witnessed a freefall which badly affected all facets of life of the general populace as cited by the United Nations UN [10]. This has been characterized by soaring inflation of $1560 \%$ as of January 2007 as noted by Bulawayo24.com/index-id-news [11]. The combination of erratic rainfall and extreme temperatures as a result of climate variability impacted negatively on the productivity of strategic food crops by both commercial and smallholder farming sectors hence exposing Zimbabwe to critical food shortages.

Generally the drastic drop in agricultural productivity compounded with unequal trade terms with developed economies under the banners of World Trade Organization (WTO) and European Union (EU) contributed immensely to the current Zimbabwe's economic meltdown which has badly affected the agricultural value chain systems Chisango [2]. Command Agriculture, which is perceived to be the brainchild of the government of Zimbabwe, therefore comes at the backdrop of a hypothesized successful land reform programme and is viewed as a vital enabler of high agricultural performance to ensure food security and increase exports from the agricultural sector to reduce poverty in the country's marginalized communities. It is opined that despite what politicians perceive as the success story behind command farming, there are numerous challenges associated with the scheme which need an urgent address if any meaningful achievement in advancing people's livelihoods is to be attained. It is therefore imperative that the study's thrust was on establishing the nature of the challenges assumed to be incapacitating the proper implementation of the program and identify what farmers perceive as opportunities that can facilitate the attainment of the desired outcomes of the program, which would finally promote its continuity and make a real difference on the lives of the marginalized Zimbabwean communities.

\section{Statement of the Problem}

The introduction of what is assumed to be the government of Zimbabwe's brain child; Command Agriculture Scheme is purported to have deprived smallholder farmers of the opportunity to participate in free open marketing systems when selling their agricultural produce. Instead the new facility prescribes that it is mandatory for farmers to sell all their produce to the Grain Marketing Board (GMB), a government parastatal, to facilitate loan repayment. Government thus determines the producer price of the produce without considering variables such as the production cost and what the free market is offering for the same product. Also, under this arrangement the government through its command economy system dictates what farmers should plant and the quantities to be produced, in an effort to ease the escalating demand of the ever growing population on food resources, and enable the country reclaim its status of being the bread basket of the Southern African Development Community SADC region. It is therefore, against this backdrop that the study is premised on examining the challenges hindering the smooth implementation and efficiency of the country's command agriculture scheme so as to unlock the potential of the program which is deemed a vital enabler of the country's agricultural economic recovery efforts; perceived as a milestone poverty reduction strategy in the smallholder farming communities of Zimbabwe.

\section{Research Objectives}

As can be drawn from the background above, the overarching objective, central to the study was; to examine the challenges and prospects of Zimbabwe's command farming as a way of advancing the country's agriculture sector, to curb poverty and food insecurity among smallholder farming communities. However the specific objectives were;

1. To examine the potential benefits and the prospects of Command farming in resuscitating Zimbabwe's smallholder farming systems.

2. To establish challenges impeding adoption and the smooth running of command agriculture programs among rural and resettlement communities, for food security and poverty alleviation among the rural populace. 


\section{Related Literature}

\subsection{Strengths of Command Agriculture}

The government of Zimbabwe adopted and implemented the Command Agriculture after realizing the menacing devastating drought of 2015 to 2016 farming season which brought the country to its knees after a perceived failed Fast Track Land Reform programme of the year 2000 Moyo [6]. It is imperative that at its inception and initial stages of implementation the programme managed to avail the much needed inputs to the resource poor farmers in an effort to boost food crop productivity. It was advantageous to the farmer as the special seasonal loan facility attracted minimal interest rates and the repayment was in the form of produce. The new arrangement where repayment was in the form of part of the yield, precisely 3 tons from an average target yield of 5 tons per every hectare funded enabled farmers to have surplus for family consumption and market for income. In addition, the programme was viewed as central in nurturing and advancing the goals of the Fast Track Land Reform (FTLR) which had witnessed a sharp decline in yields of both crop and livestock ventures since the year 2000 as alluded to by Moyo [6]. Muchara [7] furthermore cited that the adoption of command farming aimed at reducing the donor syndrome among the citizens especially through realization of enough staple food crops for consumption, was also meant to revive the country's status as the bread basket of Africa. Thus the success of the scheme was therefore viewed as an initiative that could promote the revitalization of agro-based industries hence avail job opportunities to the unemployed segment of the productive population.

\subsection{Zimbabwe's Command Agriculture Versus Good Governance, Transparency, Accountability and Social Responsibility}

Corruption which is regarded as one of the aspects of bad governance is generally acknowledged as having adversely affected previous poverty alleviation efforts in Zimbabwe. The anti-corruption crusade of the present administration through Zimbabwe Anti Corruption Commission (ZACC) is expected to have favourable implications on poverty alleviation if successfully executed. The Commission as enshrined in the country's constitution is mandated to ensure that corruption and its related vices in or by government ministries and departments at any stage of specific project/program implementation are not condoned but severely punished. It has been noted that the manifestations and problems associated with corruption have various dimensions that are retrogressive to national economic development. Among the vices prevalent in Zimbabwe; are project substitution, plan distortion, misappropriation of project finances, diversion of resources to uses for which they are not intended and even conversion of public funds to private use, as chronicled by the Chivayo saga where resources meant for the Gwanda solar farm mega project were diverted and converted to personal use by top government officials. Chivhayo a Zimbabwean bogus businessman was advanced $\$ 5$ million in controversial circumstances by Zimbabwe Electricity Supply Authority (ZESA) a subsidiary Zimbabwe Power Company (ZPC) when his company, Intratek, was corruptly awarded a tender for the Solar Power Project. The then energy minister allegedly directed (ZPC) to make the payment before any work has been commenced Bulawayo24.com/index-id-news [11]. The horrendous consequences of corruption are both directly and indirectly linked to the escalation of poverty in the country. The indirect effect manifests when there is misappropriation of resources as they are amassed by a few callous individuals in a society. This is detrimental as it stifles economic growth and retards development in a majority of nations in the region. Retarded economic growth rate leads to diminished output which impacts negatively on levels of income to channel towards developmental projects and the country's gross domestic product (GDP). Under such a scenario it is apparent that when poverty escalates the possible direct effect is that the poor are denied access to resources and facilities that could have been provided through judicious application of law to curb leakages and diversion of resources.

\section{Research Methodology}

The study was grounded on qualitative methodology and adopted unstructured interviews, key informant interviews, and secondary sources of data as data soliciting techniques. The choice of qualitative methodology was influenced by the nature of the study, which was explorative in nature and this also enabled the study to capture the attitudes and perceptions of the participants drawn from selected resettlement farms in Bindura district, namely Gatumba and Chinenga (model A1) farms to share their experiences on how they perceived challenges and prospects of command agriculture as an externally driven intervention programme. Purposive sampling or judgmental sampling was the technique used to select respondents for the study. In this case the researcher used own personal judgment to generate relevant information for the study. Through purposive sampling the researcher selected a total of one hundred (100) respondents for interviewing purpose who included ordinary farmers, village heads / chairpersons, extension officers, and ward councilors who were interviewed as key informants. In line with qualitative research the researcher adopted the thematic approach in data analysis, which helped in the description and discussion of the phenomenon or issue at hand. Data obtained were finally subjected to descriptive statistics where frequency counts, means and percentages were employed, to make conclusive deductions from the findings. 


\section{Presentations and Discussion}

\subsection{Challenges Impeding Adoption and Implementation of Command Farming Programs in Zimbabwe}

Table 1. Challenges associated with the command agriculture programs.

\begin{tabular}{lll}
\hline Nature of problem & respondents & \% response rate \\
\hline Program hijacking by politicians & 05 & 5 \\
Government interference/use of security agents not technocrats & 14 & 14 \\
Misappropriation of financial resources/rampant corruption & 15 & 15 \\
One buyer as opposed to many/monopolistic marketing & 10 & 10 \\
Under pricing of grain \&Delayed payment & 08 & 8 \\
Geographical spread of input collection depots & 11 & 11 \\
Road infrastructure and transport network & 10 & 10 \\
Zimbabwe Anti Corruption Commission's inefficiencies & 09 & 9 \\
Monopoly in supply of packaging material & 08 & 8 \\
Lack of information\& Bureaucracy in the system & 10 & 10 \\
Total & 100 & 100 \\
\hline
\end{tabular}

The findings on challenges associated with Zimbabwe's command agriculture; table 1 , above indicated that there are numerous obstacles hindering the adoption and success of the initiative, particularly in rural and small scale resettlement communities. Impediments cited by participants varied from; Government interference/use of security agents who are not technocrats with the necessary proficiency on new farming technologies, Misappropriation of financial resources and rampant corruption as highlighted in the issue of a bogus business mogul "Chivhayo." who was advanced with US\$5 million in controversial circumstances by a government parastatal, Geographical spread of input collection depots where producers from remote areas are hindered access to input resources and for GMB being the sole buyer of grain resulting in under pricing \& delayed payment for the delivered produce by farmers. Bureaucracy in the system and corrupt practices where unnecessary delays on deliveries of grain from the smallholder sector are effected by pressure from politicians and senior government officials who always solicit for favours from GMB officials, to lack of information which is regarded a crucial economic resource as it guides farmers on sound decision making.

\subsection{The Potential Benefits and the Prospects of Zimbabwe's Command Farming}

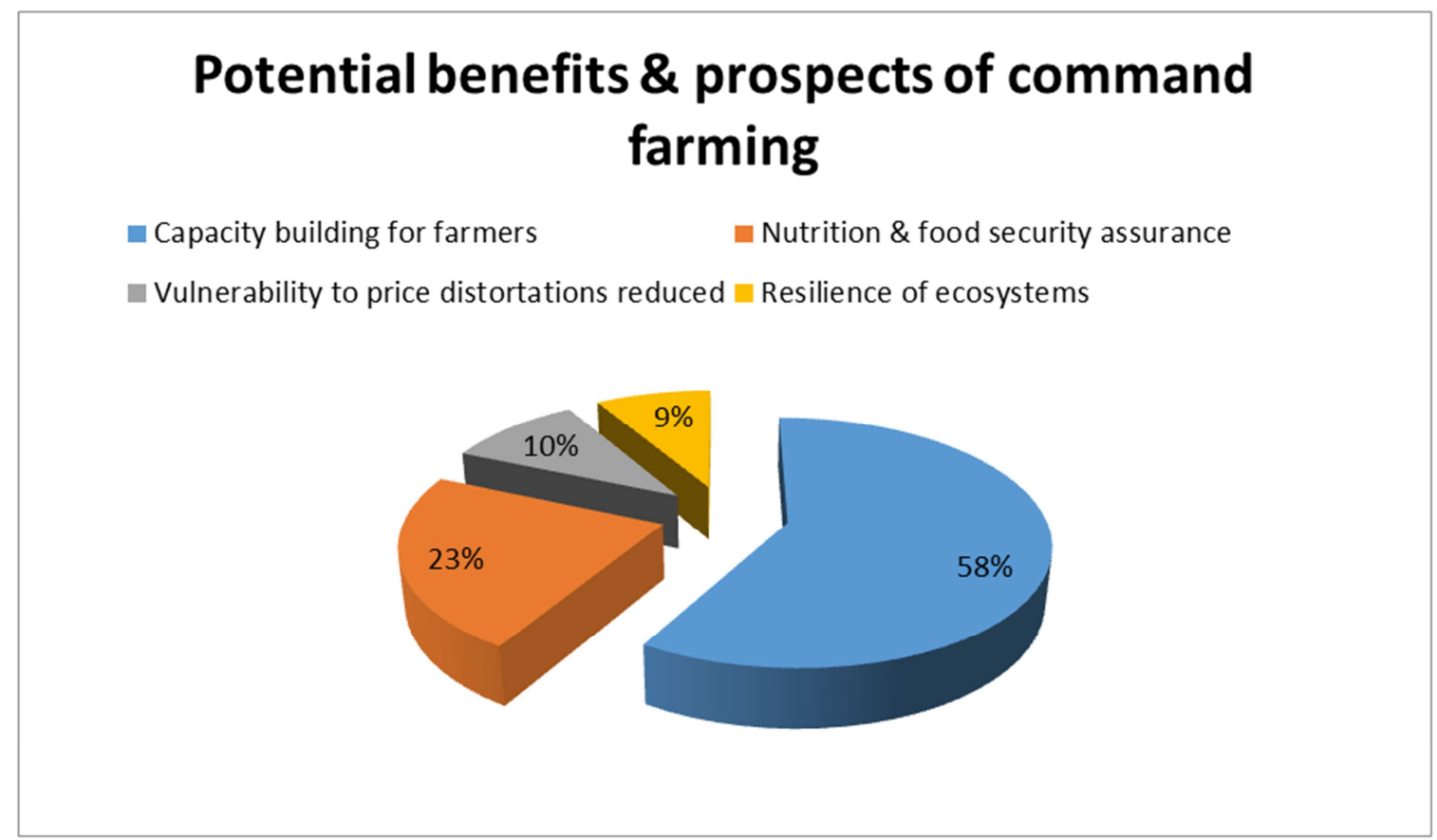

Figure 1. The potential benefits and the prospects of Zimbabwe's Command farming.

Command farming programs do not target only large scale farming, but also rural and resettlement undertakings to boost production. It is therefore imperative that during the study $58 \%$ of the participants revealed that there were prospects of a positive impact on their livelihoods as a boom in productivity would guarantee food, nutrition and income security particularly for the marginalized communities. $23 \%$ of the interviewed respondents perceived the scheme as a noble initiative in the country's endeavor to have assurance on the sustainability of nutrition and food security for the 
populace. $10 \%$ revealed that the existence of a monopsony marketing structure where the country's parastatal (GMB) was the sole buyer though giving the institution the autonomous power to determine the functioning of the frontiers of marketing and the producer price reduced the vulnerability of farmers from falling prey to unscrupulous black-market buyers who have tendencies of prejudicing farmers through price distortions as alluded to by Chisango [2]. Building resilience of ecosystems through the application of harmonized agricultural practices, integrating fisheries and wildlife management was cited as one of the strengths of command farming by $9 \%$ of the participants.

\section{Conclusions}

Numerous challenges associated with Zimbabwe's command farming program have made a wider section of farmers view the initiative as an undertaking only meant for the elite government officials who corruptly amass agricultural inputs and other resources once availed at designated collection points. The notion resulted in the generality of the population to attach less value on the scheme as they perceive the critical role of government as primarily that of setting policy and overseeing that the policy is being adhered to and create an environment that is conducive for the private sector and real technocrats to implement and monitor programs. It is only this way that fairness in the distribution of scarce agricultural resources can be achieved. It has been observed that when politics is given precedence to dictate pace and compete with the private sector important programs meant to benefit the generality of the marginalized rural communities will consequently be skewed in the wrong direction as they tend to benefit just a handful of corrupt elements in the society hence will eventually be headed for a dreadful crash.

Farmers also bemoaned the participation of state machinery/security forces in schemes meant to advance community development as they cited that people become skeptical about participating freely in such undertakings. It is generally perceived that crop farming in Zimbabwe has become synonymous with viability challenges which compel farmers to sell much of their produce at farm-gate to unscrupulous buyers, at give away prices owing to unfavourable prices offered by the government's sole parastatal; the Grain Marketing Board, thus depriving farmers of any meaningful benefit from their cropping ventures. Lack of information on the availability of viable markets from government departments such as the country's Agricultural Marketing Authority AMA and other stakeholders has rendered crop particularly grain production a futile risk not worth taking. It is however imperative that if command farming programs are to register significant success the integration of the private sector and agro-dealers is of paramount importance in the realization of the desired outcomes of the program. It is therefore critical that for the Zimbabwean government to fix its agricultural economy and advance rural development there is need for robust integration of all stakeholders and resource poor farmers at grassroots in decision making structures.

\section{Recommendations}

In light of the observations above, the study gives the following recommendations;

a) Government needs to consider a paradigm shift from a command economy system where; control is highly centralized and a large part of the economic activities are controlled by a centralized power/ a federal government to a market oriented structure, as a command economy is oppressive in that it thrives when a government in power finds itself in possession of a very large amount of valuable resources which are, to a larger extent not equitably distributed, an example being the land question and agricultural input distribution systems in Zimbabwe where politicians and top government officials are always the major beneficiaries.

b) The government should therefore advocate for a market oriented structure, where market decisions rely on the basic economic principles of supply and demand as major determinants of producer price. In this regard it is imperative that government's role would be essentially to create a stable economic environment for the market to operate justly and offer incentives for growers to boost production.

c) Politicians need to be appraised on the fundamental role of government which is the setting of policy and overseeing that the policy is being adhered to and create an environment conducive for the private sector and technocrats to implement and monitor community based developmental projects. It is only this way that fairness in the distribution of scarce resources such as agricultural inputs can be achieved.

d) A significant number of the interviewed farmers bemoaned the participation of state machinery/ security agents in schemes meant to advance community development as they cited that people become skeptical about participating and being identified with such undertakings. It is therefore imperative that politics should not be given the precedence to dictate pace and compete with the private sector in programs meant to benefit the generality of the marginalized rural communities, as this has consequently resulted in skewed resource distribution, favouring mostly the corrupt top officials in the country.

e) For profit maximization on cropping activities the government needs to stop its monopolistic tendencies in the marketing of strategic crops as this does not accord the right to farmers to bargain for viable prices. It is critical that other potential buyers or competitors with lucrative offers need to come on board so that farmers may enjoy the freedom to choose the best market where viable profit is guaranteed.

f) Unavailability of information on sound marketing from 
government departments and other stakeholders has rendered grain crop production a futile risk not worth taking. It is however imperative that if command farming programs are to register meaningful success the integration of the private sector and other agro-dealers is paramount in the realization of the desired outcomes of the program.

g) It has also been discovered that constant engagement of all stakeholders and other relevant players in grain production, and its diverse value-chain systems is always central in solving challenges which may prohibit continuity and sustainability in the production of cereals to meet the country's food requirements and advance farmers' livelihoods.

\section{References}

[1] Chandiposha et al, (2013). Source: The command agriculture exposé in full - The Standard July 2, 2017.

[2] Chisango, (2017). Impact of Zimbabwe's Current Maize Marketing Systems under a Command Economy on Grain Productivity by the Smallholder Sector; A Case of Some Selected Farms in Bindura District; Mashonaland Central Province International Journal of Science and Research (IJSR) ISSN (Online): 2319-7064 Index Copernicus Value (2015): 78. 96 | Impact Factor (2015): 6. 391.

[3] Chishamba and Mangudhla, (2017). The Standard July 2, 2017the zimbabwe commercial farmers union.
[4] Chisoko G and Zharare H, (2017). Demystifying command agriculture herald. co. zw 5 January 2017.

[5] Food and Agriculture Organization, (2007). Crop and Food Supply Assessment Mission in Zimbabwe; Special Report, Food and Agriculture Organization and World Food Program.

[6] (Moyo S, (2004). Conference on 'The Agrarian Constraint and Poverty Reduction: Macroeconomic Lessons for Africa', Addis Ababa, 17-18 December, 2004. This work-in-progress paper was presented at the conference: Comments on the paper can be sent to the author at: sammoyo@ecoweb.co.zw.

[7] Muchara B, (2009). Implications of the Fast Track Land Reform Programme on Markets and Market Relationships for Livestock, Cotton and Maize in Mwenezi District of Zimbabwe", Department of Agricultural Economics and Extension, University of Fort Hare (mimeo).

[8] Obi A and Chisango FFT, (2011). Performance of Smallholder Agriculture Under Limited Mechanization and the Fast Track Land Reform Program in Zimbabwe International Food and Agribusiness Management Review Volume 14, Issue 4, 2011.

[9] Pfukwa G, (2016), Command Agriculture offers fresh challenges.

Https://www.pindula.co.zw/Command_Agriculture_2016

[10] United Nations UN, (2006). Comprehensive Agricultural Policy Framework (2012-2032) Executive Summary April 2012.

[11] https://bulawayo24.com/index-id-news) 